\title{
Alapjövedelem - Édes bevonatú keserü pirula? ${ }^{1}$
}

\author{
OLÁH ESZTER ${ }^{2}$
}

ABSZTRAKT

A XXI. században fokozatosan elmosódik a határvonal a tradicionális foglalkoztatás és az atipikus foglalkoztatási formák között. A munkaerőpiacon fokozódó létbizonytalanság nehezíti a jóléti állam múködését, egyre többen szorulnak ki a bérmunka társadalmából, így szúkebb körre fókuszálnak a jóléti ellátások, melyek föként munkához kötődő juttatásokat jelentenek. Ilyen társadalmi és gazdasági környezetben merül fel az alapjövedelem mint a társadalmi javak elosztásának új modellje. Ez a koncepció nem kötôdik jövedelemteszthez, és nem vizsgálja a munkavállalási hajlandóságot. Ezen előnyök ellenére bevezetése nem jut tovább a kísérleti fázison, mivel alapvetô félelmek fogalmazódnak meg vele szemben. Jelen kutatás kísérletet tesz az alapjövedelemmel kapcsolatos várakozások és félelmek vizsgálatára. Egyrészt a tartalomelemzés módszerével elemzésre került néhány hírportál online felülete, fókuszálva az alapjövedelemmel kapcsolatos értékítéletet tartalmazó írásokra. Másrészt egy online kérdőívvel igyekeztünk megismerni a Debreceni Egyetem hallgatóinak értékválasztását e témában, a tartalomelemzéssel kialakított szempontok mentén.

KULCSSZAVAK: alapjövedelem, munkavállalási hajlandóság, alapjövedelemmel szembeni félelmek, értékválasztás, egyenlötlenség

\section{ABSTRACT}

\section{Basic income - Sugar-coating over a bitter pill?}

Current and future evolutions in labour markets may be blurring lines between traditional employment and new types of atypical employment, making it harder to reliably assess whether someone is receiving any benefits at all. The basic income should be seen as a serious option in the future, given the changing labor market and the finding from existing cash transfer schemes.

${ }^{1}$ A tanulmány az EFOP-3.6.1-16-2016-00022 számú projekt támogatásával készült. A projekt az Európai Unió támogatásával, az Európai Szociális Alap társfinanszírozásával valósult meg.

${ }^{2}$ Debreceni Egyetem, Szociológia és Szociálpolitika Tanszék, mesterszakos hallgató. 


\section{KEZDŐKÖR}

BI is not means-tested, so the amount received does not depend on individual or family income or assets and does not require any work performance, or the willingness to accept a job if offered.

In this study I examine the created image by the media through the method of content analysis, in relation to basic income. Furthermore, it is analyzed to what extent this effect creates a negative image of basic income among the students of the University of Debrecen, strengthening the fear towards this social policy tool. Particular attention is paid to the value choices of young people focusing on their individualization, motivation of working and willingness to take risks.

KEYWORDS: basic income, universal basic income, willingness to work, fears of basic income, welfare attitudes, inequality

\section{Bevezetés}

A 21. században a munkaerőpiac formális területének válsága nyomán növekszik azok aránya, akik alulfoglalkoztatottak és határozott idejű szerződéssel rendelkeznek (Artner 2014). A bizonytalan foglalkoztatási viszonyok egzisztenciális kérdéseket vetnek fel: hogyan lehet a mindennapi élet finanszírozásához szükséges javakat előteremteni, ha a munkához való hozzáférés lehetősége korlátozott? A megváltozott munkaerőpiaci viszonyok az anyagi szempontokon túl további problémákat is indukálnak. Az egyének karrierpályája ebben a foglalkoztatási keretben már nem lineáris, bármikor arra kényszerülhetnek, hogy alacsonyabb pozíciójú munkát is elvállaljanak vagy munkanélküliként új munkát keressenek. A munkaerőpiaci jelenlét állandó alkalmazkodást igényel a munkavállalók részéről, növelve a munkával járó stresszt és csökkentve a jövőre vonatkozó biztonság érzését (Csoba 2010). Sokan vélik úgy, hogy a digitalizáció az oka a munkalehetőségek csökkenésének, mivel a gépek egyre szélesebb körben szorítják ki az emberi munkaerőt a termelésből és a szolgáltatási szektorból (Ford 2017). A létbizonytalanság egyre nagyobb elvárásokat szül a jóléti rendszerekkel szemben, miközben - a munka világából kiszorulva - fokozatosan szűkülnek a munkához kötődő - biztosítási jellegű - juttatások. Ilyen körülmények között hogyan lehet majd szavatolni a táppénz, a munkanélküliségi ellátás vagy rokkantsági és öregségi nyugdíj biztosítását?

A munkaerőpiaci átalakulások és a növekvő elvárások a szociálpolitikai rendszerekkel kapcsolatban új típusú megoldásokat igényelnek. A megoldási javaslatok között merült fel az alapjövedelem koncepciója, tehát a személyi jövedelem állam általi garantálásának ötlete.

Jelen tanulmány kísérletet tesz az alapjövedelem differenciált fogalomrendszerének bemutatására, valamint a fogalommal kapcsolatos várakozások és félelmek elemzésére. A kutatás egyfelől a tartalomelemzés eszközével tárja fel, hogy az alapjövedelemmel kapcsolatban milyen értékkategóriák figyelhetők meg és milyen típusú félelmek jelennek meg a legolvasottabb hírportálokon. A kutatás másik pillére egy kérdőíves vizsgálat, melynek keretében a Debreceni Egyetem hallgatóinak az alapjö- 


\section{KEZDŐKÖR}

vedelemmel kapcsolatos félelmeit és értékválasztásait igyekeztünk megismerni. Az elemzés során kiemelt figyelmet fordítottunk arra, hogy egy feltétel nélkül járó jövedelem hogyan befolyásolná társas kapcsolataikat, munkavállalási motivációjukat és kockázatvállalási hajlandóságukat.

\section{A társadalmi alapjövedelem definíciós kísérletei}

A jóléti államok történetében többször felmerült az alapvető jövedelemgarancia, azaz a személyi jövedelmek állam által való garantálásának igénye. A 18. századtól erősödik az a gondolat, hogy az állampolgároknak olyan szabadon elkölthető jövedelemre lenne szükségük, amit az állam folyósít (Morus 1963, Hayek 1979, Downes - Lansley 2018). Egy ilyen típusú jövedelem gazdasági fenntarthatóságától való félelem (finanszírozás költségei) és a munkavállalási hajlandóságra gyakorolt várható hatása a korábbi századokban és napjainkban is aggodalmat szül, s ez késlelteti az állam által garantált univerzális juttatás bevezetését (Sloman 2018).

Az új modell kialakítását az sem könnyíti meg, hogy az alapjövedelem fogalmát a szakmai viták során igen eltérő tartalommal használják. ${ }^{3}$ Az elnevezések között szerepel például: „demogrant” (demográfiai mutatók szerint célzott juttatás), vagy az „allocation universelle” azaz az univerzális jövedelem (Van Parijs 1992). A koncepciók nemcsak nevükben térnek el, hanem gyakorlati megvalósításukban is, melyek a megvalósítás kidolgozásának részleteit érintik (finanszírozó kiléte, meglévő szociális transzferek csökkentése, kedvezményezettek köre).

Gyakran az alapjövedelem fogalmát párhuzamba állítják más jövedelemrendszer-koncepcióval, de ezek nem szinonim fogalmak. Ilyen rendszer, mely tisztán a jövedelemre vonatkozik a negatív jövedelemadó koncepciója (Negative Income Tax - NIT). Milton Friedman az adózáson keresztül tervezett garantált minimumjövedelmet, melynek csökken az összege a jövedelem emelkedésével (Friedman 1968). Az adó attól negatív, hogy az adómentes küszöb alattiak nem adót fizetnek, hanem javukra történik a kifizetés.

A minimumjövedelem támogatás sajátossága, hogy a jövedelemadó rendszer öszszekapcsolódik a juttatási rendszerrel és normatív alapon szabályozott (RMI - minimum income support) (Gács 1986). Ennek veszélye, hogy minimálbért képez és elveszítheti munkaösztönző hatását.

A következő megközelítés, mellyel gyakran összemossák az alapjövedelmet a részvételi jövedelem (Participation Income - PI), melynek kedvezményezettjei azok

\footnotetext{
${ }^{3}$ Az eltérő definíciók és tulajdonságok miatt eltérő gazdasági és társadalmi háttérrel rendelkező országok (Namíbia, India, Alaszka, Finnország) vizsgálják programkísérletek útján, hogy mi lehet az alapjövedelem bevezetésének gazdasági és társadalmi hatása (Eskelinen - Perkiö 2018, Downes - Lansley 2018, Arnold 2018).
} 


\section{KEZDŐKÖR}

lennének, akik elkötelezettek valamilyen társadalmilag hasznos tevékenység iránt (önkéntesség, házi munka, humántőkét növelő tevékenység, gondozás), melyet a juttatással igyekeznének elismerni (Atkinson 2017).

Ez a három elképzelés eltérő kritériumot szab meg a kedvezményezettek számára. A minimumjövedelem támogatás mindkét feltételt (rászorultság-vizsgálat és munkavállalás) elvárja a juttatásért cserébe. A részvételi jövedelem nem kötődik rászorultsági vizsgálathoz, de elvárásként határozza meg, hogy az egyén kapcsolódjon a munkaerőpiachoz. A negatív jövedelemadó, akkor is juttatható, ha az egyén egyáltalán nem rendelkezik jövedelemmel, nem kötődik munkavállalási kötelezettséghez, azonban rászorultságot vizsgál. Ezekkel szemben az alapjövedelem nem kondicionált feltételes juttatás és nem munkanélküli segélyként lehet értelmezni, amely rögtön megszűnik, ha az egyén munkába áll, tehát kombinálható más jövedelemmel.

2016-ban az egyik legjelentősebb alapjövedelmet támogató szervezet a BIEN (Basic Income Earth Network) kiadott chartája szerint az alapjövedelem rendszeres készpénz kifizetés, amit feltétel nélkül juttatnak el mindenkinek, egyéni alapon, jövedelem- és vagyonvizsgálat (means-testing), valamint munkakövetelmény nélkül (Basic Income Earth Network 2016). Ezen definíció alapján az alapjövedelem öt meghatározó vonása ${ }^{4}$ :

1. Periodikus, azaz rendszeres időközönként fizetett, nem egyszeri juttatás.

2. Készpénzjuttatás, tehát az egyén dönt a felhasználásának módjáról.

3. Egyéni alapon jár, nem a háztartásoknak.

4. Univerzális, egyetemlegesen mindenkire kiterjed, elhagyva a rászorultsági vizsgálatot.

5. Feltétel nélküli, mivel nem szab meg munkakötelezettséget és a munkára való hajlandóságot sem vizsgálja.

Jelen dolgozat az alapjövedelem értelmezése során a BIEN megfogalmazását tekinti irányadónak.

\section{Az alapjövedelemmel kapcsolatos pozitív hatások és félelmek a szakirodalomban}

Nemcsak a fogalmi megközelítések terén találkozunk az alapjövedelem sokszínűségével, hanem a várható előnyök és hátrányok felsorolásakor is. Az elmúlt három évtized meghatározó szakirodalmi áttekintéseit elemezve először arra tettünk kísérletet, hogy az egyes szerzők által az alapjövedelem bevezetésével kapcsolatban említett várható pozitív hatásokat és félelmeket megismerjük. Az így kapott eredmé-

\footnotetext{
${ }^{4}$ Valamennyi univerzális ellátás kritérium-rendszerének legmeghatározóbb vonásai.
} 
www. metszetek.unideb.hu

\section{KEZDŐKÖR}

nyekre építettük empirikus vizsgálatunk elméleti kereteit. Elsőként az alapjövedelem bevezetéséhez füződő, a szakirodalomban kiemelten megjelenő pozitív hatásokat mutatjuk be, majd a félelmeket tipizáljuk.

\section{Az alapjövedelem bevezetéséhez kötődő pozitív hatások}

\section{MUNKAVÉGZÉSRE GYAKOROLT HATÁS}

A munkavégzésre gyakorolt hatás kapcsán kiemelt jelentőséget kap az az érv, hogy az alapjövedelem biztosítaná a szabad döntés lehetőségét a munkavállalás terén, hogy az egyén milyen munkát végezzen (minőségi aspektus), és mennyit dolgozzon (mennyiségi aspektus). Ennek alapja, hogy a szociális jogosultságot és a jövedelmet leválasztja a munkaerőpiaci részvételről (egyén piaci függőségéből felszabadul), hangsúlyozva ezzel a valódi szabadságot (Van Parijs 1992). Növekedne a rugalmasság az egyén életében a munka, a szabadidő, az oktatás és a gondoskodás lehetőségeinek beosztása között (Downes - Lansley 2018). Akár hosszabb szünet is tartható két munkavállalás között, mivel a munkavégzés kényszer jellege feloldódna (Artner 2014). A felszabadult idő társadalmilag hasznos dolgokra is felhasználható, például valamilyen közösségi tevékenység végezhető. Ezen felül az emberek bátrabban lépnének ki a számukra nem kedvező munkakörülményeket biztosító állásokból, akár annak érdekében is, hogy képezzék magukat (Montemayor 2018). Ha nagyobb biztonságot tapasztal az egyén, akkor megnövekszik kockázatvállalási hajlandósága (Peltzman-hatás) (Ford 2017).

Ez a juttatás, a munkaidőt tekintve - azaz mennyiségi értelemben - kevesebb munkát tesz szükségessé. Megváltozna a részmunkaidős állások értékelése, hiszen az így megkeresett összeg, kedvező kiegészítést jelentene az alapjövedelem mellett, de kevesebb időbefektetést igényelne. Az alapjövedelem elismerné mindazok hasznos munkavégzését is, akik nem kapnak munkabért tevékenységükért (betegápolás, gyermeknevelés) (Raventos 2007).

Számos kérdést vetnek fel ezek a pozitív érvek. Többek között, hogy hogyan alakulna át a jelenleg munkára épülő társadalom? Az emberek tömegesen lépnének ki a munkaerőpiacról? E kérdések mögött az alapjövedelemmel kapcsolatos félelmek húzódnak meg. Bizonyos szempontokat fontos megragadni a pozitív érvekből: a személyi jövedelmek állam általi garantálásának terve biztosítsa a munkára való ösztönzést, az önfoglalkoztatás és részmunkaidős állások választhatóságát, mennyiségi és minőségi értelemben is. 


\section{KEZDŐKÖR}

\section{SZOCIÁLIS ELLÁTÓRENDSZERRE GYAKOROLT HATÁSA}

Az alapjövedelem univerzalitása okán elhagyja a szociális rendszerekre jellemző stigmatizáló bánásmódot (Raventos 2007). Ez az eszköz nem igényel jogosultságvizsgálatot, jövedelem tesztet vagy munkatesztet, ezáltal a jóléti rendszer bürokráciája és adminisztrációs költségei csökkenthetők (Van Parijs 2010). Foglalkoztatási státusztól függetlenül kapható, így a szegénységi csapda felszámolását is lehetővé teszi. A segélyezés mellett sokszor előfordul, hogy az egyén nem jár jobban, ha elvállal egy munkát, mivel annak jövedelme nem lesz magasabb, mint, amit a segélyezéssel elérhetne (munkanélküliségi csapda a szegénységi csapdán belül) (Raventos 2007).

Ahogyan a munkavégzésre gyakorolt hatás esetén, úgy a szociális ellátórendszerre gyakorolt hatás esetén is számtalan kérdést vetnek fel ezek a pozitív érvek. Menynyire lehet hatékony egy univerzális juttatás? Valóban képes csökkenteni a jövedelmi egyenlőtlenségeket vagy a vertikális elosztási hierarchia ugyanúgy fennmarad? A felsorolt érvek esetén szintén bizonyos vonások emelhetők, amelyet egy univerzális szociálpolitikai eszköznek hordoznia kell: csökkentse a stigmatizáló eljárásmódot és a jóléti rendszer bürokratikus eljárásrendjét.

\section{MINDENNAPI ÉLETRE GYAKOROLT HATÁSA}

Az alapjövedelem révén egy alapvető szint biztosítható, aminek mentén a szűkölködő életmód nem szűnik meg, sem a kirekesztettség, de a teljes nincstelenség felszámolható. Anyagi, szellemi, kulturális és politikai szempontból méltó életet biztosíthat (Artner 2014). Pszichológiai hatása, hogy csökken az agresszió, hiszen sokaknak lehetővé teszi a minimális biztonságot, így kevésbé kell aggódni saját túlélésükért. Ennek révén pedig csökkenhet a megélhetési bűnözés késztetéseinek többsége. Erősíti a tervezés lehetőségét, ez pedig növeli a biztonságérzetet. Egy állandó jövedelem növeli az emberek innovációra való nyitottságát és kreativitását, kiteljesítve az emberi életet. Így megnövekszik a nyitottság a családi kisvállalkozások beindítására vagy az önfoglalkoztatásra (Raventos 2007).

Azt érzékelteti ez a juttatás, hogy mindenki értékes, tekintet nélkül a személyes jellemzőkre, hogy valaki vagyonos vagy vagyontalan, ez pedig növeli a szolidaritást. Ennek eredményeképpen megerősítené a munkaerő alkupozícióját, mely csökkentené sebezhetőségüket. A munkaerő jobb helyzete a munkaerőpiacon azt eredményezné, hogy növekednének elvárásaik egy-egy munkával szemben (Artner 2014). A vállalkozó csak úgy tudna munkaerőt alkalmazni, ha javítja a munkakörülményeket és a béreket, ez pedig pozitív hatást gyakorolna a mindennapi életre. Bizonyos fokú gazdasági függetlenséget tenne lehetővé a nők számára is, így a szegénység feminizálódását is fékezné (Raventos 2007). 


\section{KEZDŐKÖR}

A juttatás lehetővé teszi, hogy a gyermek tovább őrizze meg tanulói státusát, hosszabb ideig maradjanak az iskolában elkerülve a lemorzsolódást. Az oktatás által javul az egyén munkavállalási képessége és jövedelembiztonsága. A pilot programok azt mutatják, hogy képes javítani a tápanyag ellátást, így a halálozási arányszámokat leredukálná (Ruckert et al. 2018).

Mind a szabadabb döntéshozatal a munkavégzés terén, mind a diszkriminációmentes szociális ellátórendszer, mind a pozitív hatások a mindennapi életkörülményekre lehetővé teszik, hogy az egyén olyan másodlagos kérdésekkel foglalkozhasson, mint az önmegvalósítás vagy az erősebb társadalmi kohézió kialakítása, melyekkel jobb irányba változhat életük.

\section{Az alapjövedelem bevezetéséhez kötődő félelmek}

A tanulmányokban fellelhető pozitív hatások mellett számos kritika és félelem övezi az alapjövedelmet, amelyek jelentős mértékben hozzájárulnak az új elosztási modell bevezetésének megakadályozásához. A rendelkezésre álló szakirodalom elemzése alapján a felmerülő félelmeket is három fő csoportba soroltuk be: a közgazdaságtani- finanszírozhatósági ellenérvek, a morális ellenvetések és a társadalmi típusú félelmek. A legtöbb esetben azonban ezek a félelmek nem tiszta típusként, hanem egymással kombinálva jelennek meg az írásokban.

1. táblázat: Az alapjövedelemmel kapcsolatos három félelemcsoport (saját csoportosítás alapján)

\begin{tabular}{|c|c|}
\hline FÉLELEMCSOPORT & MEGFOGALMAZOTT INDOK \\
\hline $\begin{array}{c}\text { Közgazdaságtani }- \\
\text { Finanszírozhatóság }\end{array}$ & Mi tekinthetö elegendö összegnek? $\rightarrow$ \\
\hline Morális & Gazdaságilag MEGVALÓSÍTHATATLAN \\
\hline Társadalmi & Valóban csökkenti a társadalmi egyenlötlenségeket? $\rightarrow$ \\
& Morálisan ELFOGADHATATLAN \\
\hline & Véget vetne a munkatársadalomnak? $\rightarrow$ \\
& Társadalmilag FELDOLGOZHATATLAN \\
\hline
\end{tabular}

Forrás: Saját szerkesztés

\section{KÖZGAZDASÁGTANI SZEMPONTÚ FÉLELMEK}

A közgazdaságtani félelmek kapcsán megfogalmazódik, hogy az alapjövedelem öszszegének finanszírozása gazdaságilag megoldhatatlan. Az alapjövedelem esetén fontos, hogy egy olyan szinten meghatározott összeget takarjon, amely munkaösztönző hatású (Takáts 2014). Tehát az alapjövedelem összegének egy arany középutas meg- 


\section{KEZDŐKÖR}

oldást kell megteremtenie, hogy fenntartható maradjon hosszú távon is, és pont anynyira legyen alacsony, hogy a létbiztonságot még garantálhassa mindenki számára, megtartva ezzel azt a szociális célt, amiért bevezetésre kerül. Az alapjövedelem megfelelő forrása és mértéke azért is kulcskérdés, mert befolyásolja, hogy milyen hatással lesz közgazdasági szempontból a munkaerőpiacra - főként a munkavállalás motivációjára és a munka termelékenységére - a fogyasztásra és az egyenlőtlenség mértékére.

Jelen tanulmány módszertani részében a szakirodalom alapján közgazdasági félelemként jelennek meg olyan álláspontok, miszerint az alapjövedelem csökkentené a jövedelmek értékét és a jövedelemszerző tevékenységek arányát, mely jelentős hatással lenne a makrogazdaságra is.

\section{MORÁLIS SZEMPONTÚ FÉLELMEK}

A társadalom számára elfogadott gondolkodásmód az, hogy az egyén kötelesség- és küldetéstudatot érez munkájával kapcsolatban. A munkavégzés az önbecsülést garantálja számára, ami miatt a piaci munkát nem csupán jövedelmi hasznáért végzi, hanem elvi kötelességként (Weber 1982). A protestáns etika azt közvetíti, hogy minden jutalom szenvedés árán érhető el, különben az élet értelmetlen lenne és kiüresedne. Ezt a weberi elképzelést kérdőjelezheti meg az alapjövedelem, hiszen, ha a munka általi szenvedés nélkül jut hozzá valaki alapvető forrásokhoz, akkor az emberek élete hamar kiüresedne, mert elveszítenék elvi kötelességtudatukat. Az a morális nézet, miszerint a boldog és produktív lakosság növekvő szabadideje jelentős veszélyt jelenthet a fennálló rendre nézve, fenntartja társadalmunkban azt a gondolkodást, hogy a társadalom tagjai munka árán részesülhetnek bizonyos javakban (Graeber 2018). A félelmek háttere abban gyökerezik, hogy a munka által biztosított erkölcsök devalválódása esetén nem rendelkezünk alternatív megoldással, ami a társadalom számára azt a morális támaszt nyújthatja, amelyet a munka biztosít az identitás és önbecsülés útján.

Jelen kutatásban a szakirodalom elemzése nyomán morális szempontú félelemként jelenik meg, hogy az alapjövedelem valójában nem segít leküzdeni az egyenlőtlen indulási esélyeket és így nem csökkenti a társadalmi egyenlőtlenségeket. Továbbra is fennmaradna az érdemes vagy érdemtelen szerep, lenne, aki egész nap otthon maradna, nem mutatna hajlandóságot a munkavállalásra, ez azonban nem illeszkedik a protestáns munkamorálhoz (Ford 2017). Amennyiben egyre többen lépnek ki a munkaerőpiacról, akkor azok, akik továbbra is dolgoznak altruista alapon finanszíroznák a kilépők juttatását, amely ellenérzést váltana ki, aláásva a társadalmi szolidaritást, amire a jóléti állam épül (Bo 2018). További morális félelem, hogy annak ellenére, hogy a jövedelemszegénységét csökkentené, annak kiváltó okait nem tudja orvosolni, viszont az emberek kiszolgáltatottsága nőne az állam felé. 


\section{KEZDŐKÖR}

\section{TÁRSADALMI SZEMPONTÚ FÉLELMEK}

Alapjövedelem esetén a napjainkban működő viselkedési és gondolkodási minták alapjaiban módosulnának (Takáts 2014). Félő, hogy a kedvezményezettek egy része végleg felhagyna a munkával, amennyiben havonta egy állandó jövedelemhez jutna, így a társadalmi integráció már nem a munkavállalói státusz mentén alakulna ki. Az emberek mindennapjait már nem a munkavégzés szervezné. A munka elhagyása az egyén egész életmódjára hatást gyakorolna, bérmunkatársadalom végét jelentheti, amiben az egyén a munkavégzés révén a társadalom tagjának tekintheti magát. Az alapjövedelem társadalmi csoportokra gyakorolt hatása közül kiemelkedik a nők és gyermekek helyzete. A nőkkel kapcsolatban félelemként jelenik meg, hogy a tradicionális nemi szerepek közötti munkamegosztás terén nem javulást, hanem romlást idézne elő az alapjövedelem, mivel veszélybe kerülne a nők emancipációja, visszavetve munkaerőpiaci jelenlétüket (Csillag - Mihályi 2014). Az alapjövedelem veszélyes lehet az iskoláskorú gyermekek számára is, akik esetén félő, hogy továbbtanulásuk során nem ösztönözné őket jobb iskolai teljesítményre (Anke 2018).

A társadalmi szempontú félelmek során jelen dolgozat kiemelkedőn fókuszál arra az elutasító jellemzőre, hogy csökkenne a társadalom számára hasznos tevékenységek végzésének köre és az alapjövedelem összegét káros dolgokra költenék a kedvezményezettek. Emiatt csökkenne a reciprocitás a társadalomban, ami hoszszú távon együtt járhat az emberi élet kiüresedésével, hiszen visszavetné az emberi kapcsolatok fejlődését, az egyének növekvő individualizálódásának következtében.

Mindhárom félelemcsoport esetén központi kérdésként jelent meg, hogy a személyi jövedelmek állam általi garantálása által elérhetővé válik a munkaerőpiac elhagyása. Gazdaságilag, morálisan és társadalmilag is olyan változásokat idézne elő az alapjövedelem, melyekre előre szükséges válaszokat alkotni, hiszen csak így kerülhető el, hogy bevezetése sikertelen legyen. Társadalmi szempontból a visszaeső munkavállalási hajlandóság közvetett módon az individualizálódásra és a kockázatvállalási hajlandóságra, közvetlen módon pedig a motiváció csökkenésére is hatást gyakorolna. Jelen kutatás módszertana így erre a három területre helyezi a hangsúlyt.

\section{Empirikus kutatás}

A tanulmány további része a szakirodalmakból megismert pozitív hatások és félelmek közül elsődlegesen a félelmek elemzésére fókuszál. A félelmeket több szempontból érdemes vizsgálni. Egyrészt a média az elsődleges közeg, ahonnan az egyének tájékozódhatnak. A média által közvetített tartalmak meghatározzák a társadalmi valóságról alkotott véleményt. Empirikus kutatásunk célja egyfelől annak 


\section{KEZDŐKÖR}

megismerése volt, hogy a médiumok milyen értékkategóriákat alkotnak az alapjövedelemről.

Empirikus kutatásunk második részében azt vizsgáltuk, hogy a Debreceni Egyetem hallgatói körében milyen értékkategóriák élnek az alapjövedelemmel kapcsolatban, ezen belül is a munkavállalási motivációra, kockázatvállalási hajlandóságra és a társas kapcsolatokra gyakorolt hatását. E három vizsgálati dimenzió kiemelésére azért került sor, mert a félelmek közül a munkavállalással kapcsolatos félelmek a leghangsúlyosabb a szakirodalmakban, míg a társadalmi kapcsolatokkal összefüggő értékek a kevésbé hangsúlyos helyen kerültek elő. Arra kerestük a választ, hogy a fiatalok értékválasztása hogyan változna az alapjövedelem bevezetését követően (Panitch 2011).

A téma újszerűségéből adódóan valid mérőeszköz nem áll rendelkezésre, így saját mérőeszközt állítottunk össze, melynek tesztelésére jelen kutatás keretében került sor. Ez a körülmény jelentős mértékben korlátozza a kapott eredmények általánosíthatóságát, ugyanakkor értékes információkkal szolgálhat a későbbi kutatásokhoz, mérőeszközök kidolgozásához. A médiaelemzés és a kérdőíves kutatás során vizsgált hipotézisek:

1. Az alapjövedelemmel foglalkozó cikkekben a negatív vélemények hangsúlyosabbak, mint a pozitív vélemények.

2. A közgazdaságtani félelmek (finanszírozhatóság) előfordulása gyakoribb a cikkekben, mint a társadalmi félelmek csoportja.

3. Az alapjövedelem hatást gyakorolna az individualizáció fokozódására.

4. Az alapjövedelem hatást gyakorolna a munkavállalási motivációra, mind mennyiségi, mind minőségi összetevők esetén.

5. Az alapjövedelem növelné az egyének kockázatvállalási hajlandóságát.

\section{Tartalomelemzés}

A tartalomelemzés alkalmazásának célja, hogy tisztább képet kapjunk azokról az értékkategóriákról, amelyeket a médiumok közvetítenek az alapjövedelemről. Mivel egy kvantitatív elemzésről van szó, így numerikus eredmények születtek, lehetővé téve induktív következtetések levonását.

A tartalomelemzés során vizsgált mintát két országos napilap képezte: a Magyar Idők és a Népszava, ezen kívül három országos hetilap is elemzésre került, a $H V G$, a Magyar Narancs és a 168 óra. Az elemzés alapjául ezen oldalak online archívuma szolgált, hiszen feltételezhető, hogy az egyetemista fiatalok az online platformokat részesítik előnyben. Az online tér jelentősége miatt két gyakran látogatott internetes hírportál is elemzése került: az Index és Origo weboldalak. A tartalomelemzés alapját a hét mintavételi egység alkotta. Azok az írások kerültek elemzésre, amiben 


\section{KEZDŐKÖR}

az alapjövedelem kifejezés megjelenésén túl (keresési kritérium: „alapjövedelem” kifejezés), megfigyelhető a juttatás elemzése, tehát értékítélet társul a közléshez. Azok, az írások, amelyekben megemlítik az alapjövedelem kifejezést, vagy utalnak rá, nem kerültek az adatbázisba, mivel ezek közvetlenül nem hatnak az olvasó értékválasztásaira. A vizsgált időtartam 2013 és 2018 szeptembere közé esett. Az elemzéshez adatbázis került kialakításra, melybe néhány jelentősebb információt hordozó szempontot rögzítettünk: a sajtótermék nevét és jellegét (naponta vagy hetente jelenik meg a médium), a cikk megjelenésének idejét és témáját (nemzetközi vagy hazai esemény ihlette). Ezenkívül a hipotézisek vizsgálatához szükséges volt, hogy a cikk milyen értékkategóriába sorolható be, inkább negatív, inkább pozitív vagy semleges képet közvetített. Semleges kategóriába az a cikk kerülhetett, amelyben egyformán megtalálhatók voltak az érvek és ellenérvek. A hipotézis vizsgálat alapja volt az is, hogy ha negatív képet alakít ki az adott cikk, akkor melyik - jelen kutatás által lehatárolt - félelemcsoportba sorolható be (közgazdaságtani/morális/ társadalmi). Ezek a szempontok Excel táblázatban kerültek rögzítésre az elemzett 192 darab cikk esetén, melyek lebontását a 2. táblázat szemlélteti.

2. táblázat: Közlemények száma évek és sajtótermék szerint lebontva

\begin{tabular}{|l|c|c|c|c|c|c|c|}
\hline Sajtótermék neve & $\mathbf{2 0 1 3}$ & $\mathbf{2 0 1 4}$ & $\mathbf{2 0 1 5}$ & $\mathbf{2 0 1 6}$ & $\mathbf{2 0 1 7}$ & $\mathbf{2 0 1 8}$ & Összesen \\
\hline Népszava & 3 & 5 & 5 & 15 & 10 & 4 & 42 \\
\hline Magyar Idók & 0 & 0 & 1 & 8 & 9 & 2 & 20 \\
\hline HVG & 2 & 14 & 12 & 15 & 14 & 5 & 62 \\
\hline Magyar Narancs & 3 & 0 & 3 & 0 & 4 & 0 & 10 \\
\hline 168 óra & 0 & 2 & 1 & 3 & 6 & 1 & 13 \\
\hline Origo & 0 & 3 & 1 & 8 & 2 & 0 & 14 \\
\hline Index & 4 & 5 & 3 & 6 & 10 & 3 & 31 \\
\hline Összesen & 12 & 29 & 26 & 55 & 55 & 15 & 192 \\
\hline
\end{tabular}

Forrás: Saját szerkesztés

A táblázatból kitűnik, hogy a 2016-os és 2017-es évben az alapjövedelemmel kapcsolatos diskurzus kiugrónak mutatkozik, ami a Svájcban zajló népszavazásnak és a 2017-ben bevezetésre kerülő finn kísérletnek köszönhető.

\section{Kérdőíves vizsgálat}

Az alapjövedelemmel kapcsolatos attitűdök feltárására irányuló kutatásunk második elemét egy standardizált kérdőív alkotta. A kérdőív alkalmazását az motiválta, 


\section{KEZDŐKÖR}

hogy megismerjük a tartalomelemzés során hangsúlyos félelmek milyen formában jelennek meg a fiatalok értékválasztásaiban. Mindemellett arra is kíváncsiak voltunk, hogyan hatna - egy havonta kapott összeg, teljesítménykényszer nélkül - a kitöltőkk egyéni- és társas életvitelük egyensúlyára, munkavégzési motivációjára és kockázatvállalására. A lekérdezés a Debreceni Egyetem hallgatói körében történt, online kérdőív formájában, önkéntes alapon a Google kérdőívkészítő alkalmazásával. A mintába olyan egyéneket emeltünk be, akik dolgoztak már egyetemi tanulmányaik alatt, így a megkérdezettek többsége nemcsak szünidőben dolgozott (24\%), hanem szorgalmi időszak alatt is (76\%).

A strukturált kérdőív kitöltésére 2018. október 2. és 2018. október 24. között került sor. A megkérdezettek személyes adatait az adatvédelemre vonatkozó követelmények betartásával kezeltük a lekérdezés és az elemzés során, ennek alapjául szolgált a kérdőív elején a tájékoztató és beleegyező nyilatkozat feltüntetése. A szociodemográfiai kérdéseken túl az alapjövedelemmel kapcsolatos véleményükre konkrétan kérdezett rá a kérdőív. Eltérő felsoroláshoz jutott a kitöltő attól függően, hogy elutasító vagy támogató a hozzáállása a témában. Kiválaszthatták azokat az itemeket, amelyek meghatározzák attitűdjeiket. Harmadik opcióként választható volt az is, hogy nem tud véleményt alkotni. A kérdőív utolsó részében a „Mit tennél, ha...?" típusú kérdések kaptak helyet, ezeket a jelenlegi helyzetük alapján, és egy elképzelt szituáció szerint is meg kellett válaszolniuk. Eszerint, minden hónapban, kötelezettségek nélkül jutnának 50 ezer forintnyi alapjövedelemhez, teljesítménykényszer nélkül.

A kérdőív nem tartalmaz nyitott kérdéseket, a zárt kérdések azonban széleskörủ válaszlehetőségeket kínáltak és ahol erre volt lehetőség, feltüntetésre került az „Egyéb” kategória is, így a zárt válaszok tartalmaztak nyitott kategóriát is, hogy a kutatói megfogalmazás mellett, a válaszadók megjeleníthessék önálló véleményüket is. A kérdőívet kitöltése előtt próbakérdezésnek vetettem alá egy 10 főből álló csoportban, az általuk adott visszajelzések alapján megtörténtek a szükséges módosítások. A végleges kérdőívre 145 válasz érkezett. A nem valószínűségi mintavétel miatt nem tekinthető reprezentatívnak, így a kapott eredmények nem alkalmasak végérvényes következtetések levonására. Kismintás kutatásunk csupán azt teszi lehetővé, hogy az alapjövedelem megítélésével és bevezetésének várható hatásával kapcsolatban néhány összefüggést és tendenciát felvázoljunk.

\section{Hipotézisvizsgálat}

\section{Az alapjövedelemmel foglalkozó cikkekben a negatív vélemények társadalmi szinten hangsúlyozottabbak, mint a pozitív vélemények.}

A hipotézis kiindulópontja, hogy a tartalomelemzés által elemzett felületeken milyen számban képviseltették magukat az egyes értékkategóriák - pozitív, nega- 


\section{KEZDŐKÖR}

tív, semleges. Összességében a negatív vélemények nem fordulnak elő túlnyomó többségben az elemzett írásokban (48 darab). A pozitív tartalmú üzenetek nagyobb számban jelennek meg (64 darab). Tehát nem mondható, hogy az olvasók nem kapnak objektív tájékoztatást arról, hogy az alapjövedelem csapda-e vagy lehetőség. Ezen hipotézis tehát nem teljesül, mivel a negatív értékkategóriát tartalmazó írások nincsenek túlsúlyban a tartalomelemzés által készített adatbázis szerint. A cikkek közel felét a semleges hangvételú cikkek teszik ki, ami azt mutatja, hogy a befolyásolás nem billen el szélsőséges irányba, hanem kiegyensúlyozott marad (80 db).

A félelmek kialakításában a média nem játszik főszerepet, így a félelmek vélhetően a közvéleményben rejlenek. A félelem mélyen beágyazott, mivel - a grassroot megközelítés szerint - az egyének által vallott értékekből és attitűdökből tevődik össze a pánikképződés (Kitzinger 2000). Az emberek életében a fenyegetettség érzése az egzisztenciális kiszolgáltatottság kapcsán felerősödik, emberi természetünkből ered a törekvés létfenntartásunk megőrzésére (Policy Agenda 2018). Alapjövedelem esetén az újszerű eszközzel szemben a fenyegetettség érzése őszinte, hiszen az emberek saját megélhetésük miatt aggódnak. A média tehát nem tud ott félelmet kelteni, ahol korábban nem volt alapja.

2. Az alapjövedelemmel foglalkozó cikkekben a közgazdaságtani félelmek (finanszírozhatóság) elöfordulása gyakoribb, mint a társadalmi félelmek csoportja.

Az elemzés alapján ez a hipotézis alátámasztható, mivel a finanszírozhatóság kérdésköre összességében a leggyakoribb félelemtípus, ami megjelenik a cikkekben. A 1. ábrán látható, hogy a morális félelmek és a társadalomra gyakorolt hatás kevésbé jelenik meg a közlések szintjén.

1. ábra: Cikkek csoportosítása félelemcsoportok szerint (db)

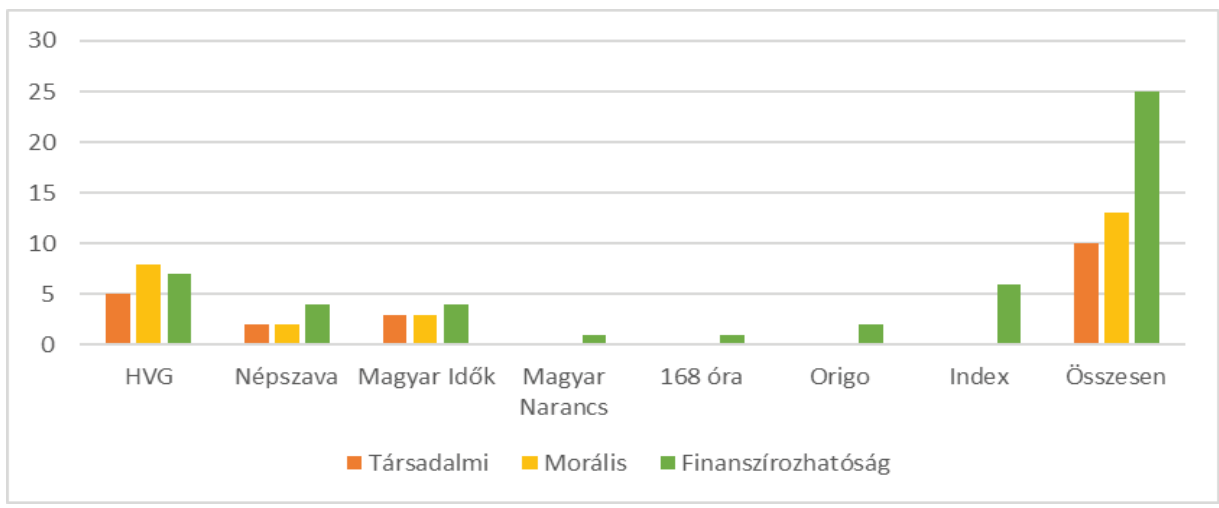

Forrás: Saját szerkesztés 


\section{KEZDŐKÖR}

A kérdőívben felsorolt elutasító itemek is csoportosíthatók a három félelemcsoportba, ezek megoszlásai megmutatják, hogy melyik félelem a markánsan megjelenő a kitöltők között. A tartalomelemzés során felállított félelemcsoportok közötti rangsor alátámasztható a kérdőíves válaszokkal is. A kitöltő egyetemisták körében a finanszírozhatóság kérdésköre az, amely a legnagyobb félelmeket váltja ki (40\%). Azonban pozitív tény, hogy a morális félelmek $(38,4 \%)$ sem szakadnak el túlságosan a közgazdaságtani félelmektől. Tehát a kérdőív kitöltői a pusztán anyagi megfontolásokon túl azon is gondolkoznak, hogy mi helyes és helytelen ezzel kapcsolatban. A társadalomra gyakorolt hatását az alapjövedelemnek a válaszadók is nehezebben tudják elképzelni (21,6\%), így ez - ahogyan a cikkekben is - harmadlagos félelemcsoportként jelenik meg.

A finanszírozhatóság kérdéskörének gyakoribb megjelenése - mind a tartalomelemzésben, mind a kérdőív válaszaiban - magyarázható azzal, hogy ezen érvelés alátámasztható statisztikai adatokkal, melyek mutatják, hogy a gazdaságot hogyan terhelné meg a juttatás, így ezek a félelmek érthetőbbek. Továbbá a megélhetés biztosítása mindig központi helyet foglal el az emberek életében, a jövőtől való félelem genetikánkba kódolt. Az egyén először arra törekszik, hogy az anyagi jellegú, létbiztonsággal kapcsolatos szükségleteit kielégítse (Inglehart - Flanagan 1987). Így a jövőtől való félelem összefügg az egyén rendelkezésére álló jövedelemmel. Ez aktiválja az emberek azon félelmét, hogy a megszokott életszínvonalukat és anyagi biztonságukat sodorná veszélybe egy egyetemlegesen biztosított szociálpolitikai eszköz. Hiszen, félő, hogy egy szélesebb lefedettséget megvalósító szociálpolitikai ráfordítást az adott ország államháztartása nem tudna megvalósítani hosszú távon. A morális és társadalmi hatásai az alapjövedelemnek nehezen megjósolhatók. A társadalom reakciója kiszámíthatatlanabb és nehezebben értelmezhető, még a gazdasági folyamatoktól is.

Direkt módon megkérdezésre került, hogy mit gondolnak az alapjövedelem eszközéről, az egzakt kérdés nem sugalmazott semmilyen értékítéletet. A válaszadók kisebb része utasítja el ezt a juttatást (30\%), többségük jó ötletként tekint rá (49\%) és a kitöltők $21 \%$-a nem tudott véleményt alkotni róla, aminek a kérdés értékítéletmentessége lehet az oka. A kérdés megfogalmazásának fontosságát mutatja, hogy az 1000 fős mintán elvégzett Republikon kutatás pozitív értékekkel ruházta fel az alapjövedelmet, mikor támogatottságát kutatta: létbiztonságot garantál, az alacsony fizetéseket is emeli (Republikon 2016). Ennek eredményeképpen a megkérdezettek csak 7\%-a nem tudott véleményt alkotni az alapjövedelemről, de magas volt azok aránya, akik támogatnák a javaslatot (76\%), míg 17\%-uk nem állt ki a juttatás mellett. 


\section{KEZDŐKÖR}

\section{Az alapjövedelem hatást gyakorolna az individualizáció fokozódására.}

Ez az állítás négy szempont szerint került vizsgálatra. Eszerint a társaságba járás - alapjövedelem esetén - felszabadul az anyagi korlátok alól, hiszen a válaszadók 32\%-a jelenlegi helyzetében egyetért azzal, hogy nem szeret társaságba járni, hiszen költséges. Ez az arány alapjövedelem esetén kevesebb, mint 6\%.

Önkéntes munkát nagyobb arányban vállalnának alapjövedelem esetén, míg a jelenlegi helyzetben megoszlik arról a vélekedés, hogy hallgatóként mennyiben éri meg ez a tevékenység. A válaszadók 46\%-a egyetért azzal jelenlegi helyzetében, hogy azért nem végez önkéntes munkát, mert nem jár érte fizetség. Alapjövedelem esetén az egyetértők aránya 27\%-ra csökken.

A barátokkal és rokonokkal való utazás lehetősége nőne, ha minden hónapban egy fix juttatást kapnának kézhez. A válaszadók 72\%-a egyetért azzal a kijelentéssel, hogy sokat utazna szeretteivel.

Amennyiben járna az alapjövedelem a válaszadók döntő többsége (90\%) inkább a szabadidőt választaná, amelyet a családdal és a barátokkal tölthet, minthogy olyan munkája legyen, ahol sokat kereshet. Míg a jelenlegi helyzetben csak 74\%-uk véli úgy, hogy a családdal töltött szabadidő fontosabb, mint a jó pénzkereseti lehetőség.

A négy állításra adott válaszból megállapítható, hogy a harmadik hipotézis nem teljesül, ezen dimenziók szerint. Mivel a kitöltők életében az állandó juttatás hatására nem fokozódna az individualizáció, a vizsgált aspektusok alapján. Inkább a megnövekedett szabadidőt társasági életre és önkéntes munkára fordítanák, amellyel aktívabb és altruistább tagjai lehetnének a társadalomnak. Míg a jelenlegi helyzetben a tanulás és a vállalt munka mellett kevesebb lehetőségük jut olyan tevékenységek végzésére, amellyel jobban kötődhetnének a társadalomhoz. Egy garantált jövedelem lehetőséget teremtene az egyén számára a munka, a szabadidő, az oktatás és a gondoskodás tevékenységeinek jobb elosztására (Downes - Lansley 2018). A felszabadult idő társadalmilag hasznos dolgokra használható, például közösségi tevékenység végezhető, amely egyértelmű pozitív hatást gyakorol a kohézióra (Artner 2014).

\section{Az alapjövedelem hatást gyakorolna a munkavállalási motivációra, mind mennyiségi, mind minőségi összetevők esetén.}

A motivációhoz nyolc állítást rendelt a kérdőív, ezek a munkavállalás minőségi és mennyiségi összetevőire egyaránt irányultak. A válaszadók esetén nincs jelentősebb eltérés a jelenlegi és alapjövedelmi helyzetben, hogy szívesen dolgoznak-e. A kérdezettek közel hasonló arányban dolgoznának szívesen, alapjövedelem esetén is (80\%), mint jelenleg (74\%).

A jelenlegi helyzetben a válaszadók 79\%-a egyetért azzal, hogy az egyénnek dolgoznia kell annak érdekében, hogy mindent meg tudjon vásárolni, amire szüksége van. A munkavégzés motivációjának fennmaradását mutatja, hogy alapjövede- 


\section{KEZDŐKÖR}

lem esetén a válaszadók magas aránya (64\%) továbbra is dolgozna, hogy mindent megtudjon vásárolni magának, amire szüksége van. Ennek a két állításnak a pozitív eredményei utalhatnak arra, hogy alapjövedelem esetén nem csökkenne jelentősen a munkavállalási hajlandóság. Az megkérdezettekben erőteljesen élnek azok az értékek, amelyek mentén az egyén küldetéstudatot érez a munkavégzéssel kapcsolatban, mely önbecsülést garantál számára. Így a piaci munkát nem csupán jövedelmi hasznáért végzi, hanem elvi kötelességként, mely identitást biztosít számára és lehetővé teszi az önmegvalósítást is (Weber 1982). A bérmunka társadalmában szocializálódott egyének a válaszok alapján nem látnak másik utat boldogulásukhoz, csak a munkavégzést, ilyen értelemben nem változna számottevően a megkérdezett hallgatók morális hozzáállása a munkavégzéshez.

A válaszadók több mint fele (65\%) vállalna munkát egyetemi tanulmányai mellett, alapjövedelem esetén is. Válaszukat alapvetően befolyásolhatta az alapjövedelem összege is, lehet, hogy valaki nem tartotta elegendőnek ezt az összeget, így döntött a válasz mellett. A kérdőívben megadott 50 ezer forintos összeg a korábbi magyarországi számításokat vette alapul (LÉT 2014, Párbeszéd Magyarországért kiadványa 2015). Ezen összeget megítélhették úgy a válaszadók, hogy emellett szükség lenne arra, hogy munkát vállaljanak. Azonban így valószínúleg érvényes az a gondolat, hogy az alapjövedelemnek nem sikerülne teljesen dekommodifikálnia a munkaerőpiacot, mivel az egyéneknek nem lenne elegendő az a pénzösszeg, amit kézhez kapnának (Wright 2006).

Kirajzolódik az az elvárás, hogy a vállalt munka ahhoz a területhez kapcsolódjon, amelyet tanul az egyén, hiszen a kitöltők 64\%-a gondolja úgy, hogy egy ilyen szociálpolitikai eszköz mellett erre nagyobb lehetőségük lenne, mint jelenleg. A jelenlegi helyzetben az egyetértők aránya csak 45\%, így az aktuális állapot a kötöttségekkel azonosítható. Hiszen magas azok aránya, akik nem olyan munkát végeznek, mely kapcsolódna tanulmányaikhoz (56\%). Az alapjövedelmi helyzet egy szabadabb döntéshozatalt szimbolizál a munkavégzés minősége terén, mely igény megjelent a válaszadók értékválasztásaiban is. Egy garantált jövedelem esetén a társadalom tagjai szabadabban dönthetnének arról, hogy milyen munkát vállalnak, mivel a munkavégzés kényszer jellege feloldódna (Artner 2014).

A munkavégzés kapcsán felkínálásra került néhány lehetőség a munkavállalás okaként, ezt a 2. ábra szemlélteti. Ezekből a jellemzőkből kiderül, hogy az önmegvalósítás, az álmok követése és a sikerélmény átélésének szerepe közel kétszeresére növekedne alapjövedelem esetén. Míg a jelenlegi helyzetben az anyagiaktól (anyagi függetlenedés vágya a szülőktől, anyagi kényszer) és a munkaerőpiaci elvárásoktól (tapasztalatszerzés vágya, segíti az érvényesülést, jól mutat az önéletrajzban) való függés határozza meg az egyén munkavállalásának okát. Tulajdonképpen kényszer szüli azt, míg alapjövedelem esetén a valódi szabadság jelszava választási szabadságként lehetőségeket teremt (Wilder 2018). 
www. metszetek.unideb.hu

\section{KEZDŐKÖR}

2. ábra: „Mi a munkavállalásod oka?” kérdésre adott válaszok megoszlása (\%)

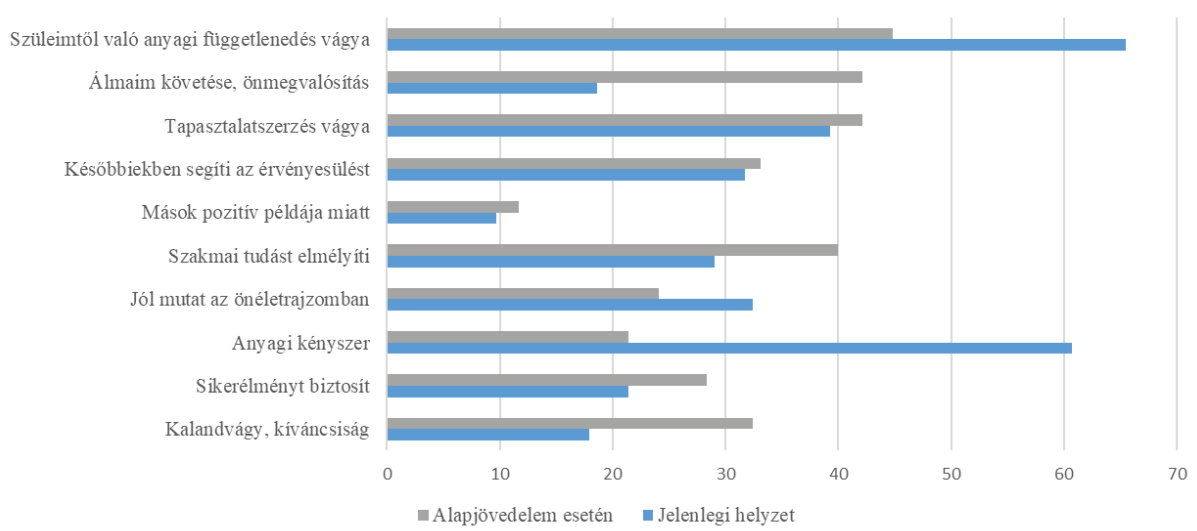

Forrás: Saját szerkesztés

Hasonló eredményeket mutatott a legfontosabb motiváló tényezők felsorolása is (3. ábra). A jelenlegi helyzetben a munkavégzést kényszer szüli - közel legyen a munkahely a lakóhelyhez vagy magas pénzbeli elismeréssel járjon.

3. ábra: „Mit tekintesz legfontosabb motiváló tényezőnek, munkavégzésed szempontjából?” kérdésre adott válaszok megoszlása (\%)

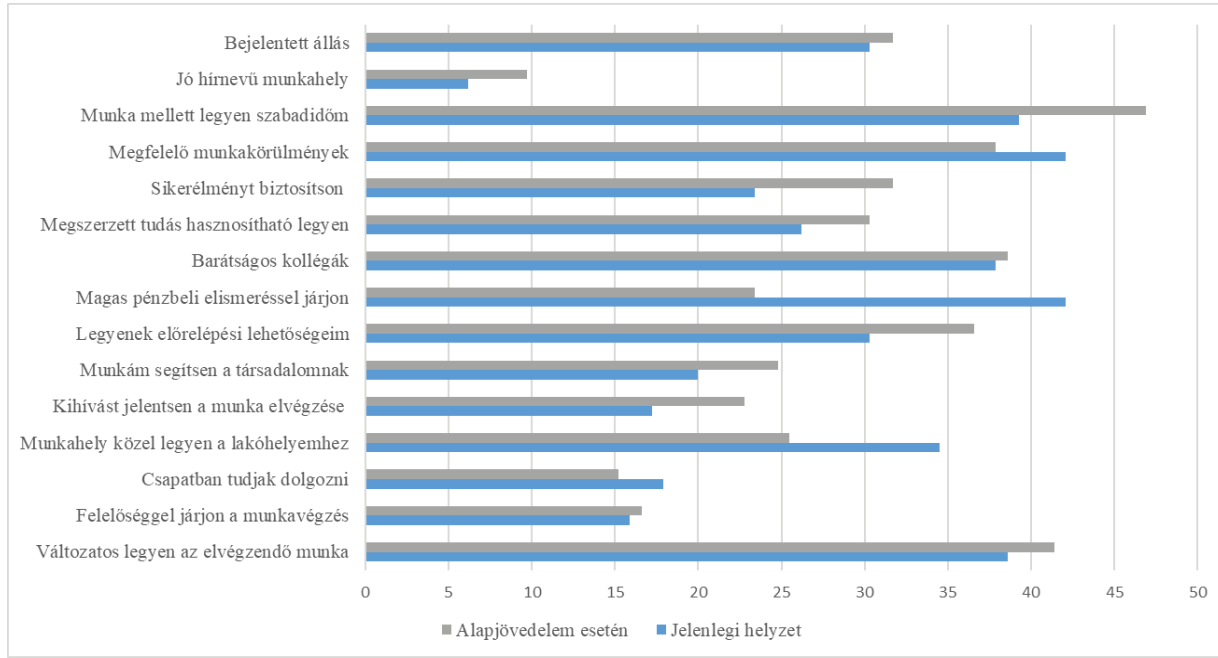

Forrás: Saját szerkesztés 


\section{KEZDŐKÖR}

Egy univerzális juttatás esetén azonban más célok motiválják az egyén munkavégzését. Fontossá válna, hogy kihívást jelentsen az elvégzendő munka, legyenek előre lépési lehetőségek és sikerélményt biztosítson. A kitöltők igényelnék, hogy munkájuk segítsen a társadalomnak, hogy a társadalom hasznos tagjai lehessenek. A munkavállalás okaiban és a munkavégzés motiváló tényezőiben bekövetkező eltolódások magyarázhatók azzal, hogy ha az egyénre nem nehezedik az anyagi kényszer, akkor másodlagos kérdésekkel is elkezdhet foglalkozni, amelyek révén életét értelmesebbé teheti. A kielégített materiális értékorientációk elvezetnek a magasabb rendű szükségletek felismeréséhez, amik erősítik a társadalmat (Inglehart Flanagan 1987).

A munkavégzés mennyiségi összetevőire utalva a kérdőívben szerepelt kérdésként, hogy: „Heti hány órát fordítasz munkavégzésre?”. Ennek elemzéséből megállapítható, hogy alapjövedelem esetén bekövetkezne a vállalt munkaórák minimális csökkenése a megkérdezettek körében. A 30 óra feletti munkavégzés a jelenlegi helyzetben a válaszadók 21\%-ára jellemző, alapjövedelem esetén ez 14\%-ra csökken és az 5-20 óra közötti munkavégzés preferálása kerül előtérbe. A mennyiségi változás az egyetemisták munkavállalási hajlandóságában nem egyenlő azzal, hogy teljesen felhagynának a munkavégzéssel. Hiszen a hozzáállásuk nem módosulna jelentősen a megkapott pénz hatására sem, csak rugalmasabban dönthetnének az elvállalt munka minőségéről és mennyiségéről.

A negyedik hipotézis nem igazolható maradéktalanul, mivel minőségi és mennyiségi változások történnének a munkavállalók hozzáállásában, a hallgatók válaszai alapján. Azonban a direkt kérdések terén, motivációjuk esetén ez a változás nem mutatható ki és az átalakulásra irányuló válaszok sem szélsőségesek. Alapmotivációjuk nem változna, továbbra is vállalnának munkát, de a hozzáállásuk minőségi és mennyiségi változásokat hívnának életre a munkaerőpiacon. Egy olyan társadalomban, ahol a munkavégzés önmagában erkölcsi értéket jelent ott a munkavállalás kényszerének feloldódása a weberi protestáns munkamorál végét jelentheti, ami a bérmunka társadalmát is veszélyezbe sodorhatja. Alapjövedelem esetén a fennálló rendszer módosulna - mind mennyiségi, mind minőségi vonatkozásban - ezt mutatják a kérdőív válaszai. Ezek a válaszok a hallgatók értékválasztásait mutatják, melyek nem azonosak cselekedeteikkel, illetve a változások mértékét sem szemléltetik. Ha a társadalmi javak elosztásának egy új formáját alakítják ki, amely független a munkavégzéstől, akkor kiszámíthatatlan, hogy milyen következményekkel járna a bérmunka társadalmának átalakulása, pedig ebben rejlik a félelmek valódi alapja. Arra nem tudunk választ adni, hogy ha véget ér a bérmunka társadalma, akkor hogyan adjunk értelmet életünknek egy olyan világban, ahol már nem a munka a meghatározó. 


\section{KEZDŐKÖR}

\section{Az alapjövedelem növelné az egyének kockázatvállalási hajlandóságát.}

Ezen hipotézis igazolására négy kérdés került megfogalmazásra, melyet a 6. ábra tartalmaz. Az egészséges életmódra a jelenlegi helyzetben is próbálnak odafigyelni a kitöltők, mivel 62\%-uk egyetért az egészséges életmód fontosságával. Alapjövedelem esetén mégis látható a pozitív tendencia, miszerint még fontosabbá válik, hogy beruházzanak az egészséges életmódba, a válaszadók 92\%-a szerint.

A jelenlegi helyzet megosztó képet mutat, de a hallgatók 58\%-a pénzügyileg sokszor támaszkodik családjára. Ahogyan az egészség kérdéskörében, úgy itt is látható a változás, hiszen érezhető az erőteljesebb függetlenedési vágy alapjövedelem esetén (22\%-uk támaszkodna családjára) mely mögött ott áll a plusz pénz nyújtotta biztonság. Amennyiben nagyobb biztonságot tapasztal az egyén, akkor növekszik a kockázatvállalási hajlandósága (Ford 2017).

A kockázatvállalás fokát vizsgálva megállapítható, hogy ebben is változások következnének be. Hiszen a válaszadók 25\%-a nem ért egyet azzal, hogy alapjövedelem esetén az akciós ajánlatokat keresné vásárláskor. A jelenlegi helyzethez képest tapasztalható változás, hiszen ebben az esetben 13\%-uk nem keresi az akciós termékeket vásárlás során. Megfigyelhető az elmozdulás, de nem számottevő, tehát alapjövedelem esetén sem valószínű, hogy a kedvezményezett szélsőséges kockázatvállalási hajlandóságot mutatna.

A mostani helyzetükben a kitöltők 70\%-a inkább elutasítja a drága és márkás termékek vásárlását. Alapjövedelem esetén ebbe az irányba is megfigyelhető a nyitottság és a háttérben meghúzódó növekvő anyagi biztonság érzése, mivel a válaszadók 58\%-a utasítja el a márkás termékek beszerzését.

Ezen változások azzal magyarázhatók, hogy a megkérdezettek részesülhetnének a szabadabb döntéshozatal élményében, ami a kényszer nélküli időbeosztást és szabad életstílus választás lehetőségét biztosítaná számukra (Standing 2012). Alapjövedelem esetén a materiális értékorientációk kielégítése magasabb szinten lenne biztosítható.

A kutatás 5 vizsgált hipotézise közül az első és a harmadik cáfolásra került, míg a második, a negyedik és az ötödik igazolást nyert. Annak ellenére, hogy a finanszírozhatóság kérdéskörével a média többet foglalkozik és a hallgatók közvetlen értékválasztásaiban is gyakrabban jelenik meg, mégis a közvetett kérdések esetén a munkavállalási motivációra és kockázatvállalásra adott válaszok azt mutatják, hogy a társadalmi és morális félelmek - rejtetten jelennek meg - nem alaptalanok. A motiváció és kockázatvállalás terén bekövetkező változások megalapozzák a félelmeket, amelyek arról szólnak, hogy hogyan adjunk értelmet életünknek egy olyan világban, ahol már nem a munka lesz a meghatározó integráló erő, mely az önmegvalósítás lehetőségét biztosítja az emberek számára. 


\section{KEZDŐKÖR}

\section{Összegzés}

Jelen kutatás célja volt, hogy feltárja a személyi jövedelmek állam általi garantálásával kapcsolatos félelmek jellemzőit a kiválasztott célcsoportban megjelenő értékválasztások mentén. Továbbá törekedtünk annak vizsgálatára is, hogy a média milyen értékkategóriákat hangsúlyoz a témában.

A szakirodalmak elemzése révén a félelmek három markáns csoportba sorolhatók be: közgazdaságtani, morális és társadalmi félelmek. A kutatás empirikus részében megállapításra került, hogy az alapjövedelemmel foglalkozó cikkekben a negatív vélemények társadalmi szinten nem mutatkoznak túlhangsúlyozottnak a pozitív véleményekhez képest. A médiumok tájékoztatása a vizsgált témára vonatkozón összességében objektív maradt. Az alapjövedelemmel foglalkozó cikkekben a közgazdaságtani félelmek (finanszírozhatóság) előfordulása gyakoribb, mint a morális és társadalmi félelmek csoportja. A félelmek megjelenésének sorrendje a kérdőív kitöltői között is hasonlóan alakul. Esetükben is a finanszírozhatóság az a problémakör, melyet releváns veszélynek látnak az alapjövedelemmel kapcsolatban, míg a fennálló társadalmi rend átalakulásától való félelem kevésbé jelenik meg a válaszokban. Cáfolásra került az a hipotézis, miszerint az alapjövedelem fokozná az individualizációt. Alapjövedelem esetén a megnövekedett szabadidőt jelentősebb társasági életre és önkéntes munkára fordítanák, mellyel növelhetnék a társadalmi kohéziót.

Vizsgálatra került az a hipotézis, hogy az alapjövedelem negatív hatást gyakorolna a munkavállalási motivációra, mind mennyiségi, mind minőségi összetevők esetén. A munkavállalási hajlandóságot tekintve a válaszok alapján érzékelhető, hogy az egyén kötelességtudatot érez munkájával kapcsolatban, mely önbecsülés ad számára, így a munkát nem pusztán jövedelmi hasznáért végzi, hanem elvi kötelességként. Megállapítható, hogy minőségi és mennyiségi változások történnének a munkavállalók hozzáállásában, de a direkt kérdések terén, ami a motivációjukra vonatkozik ez a változás nem mutatható ki és az átalakulásra irányuló válaszok sem mutatnak szélsőséges irányváltozásokat. Az elemzés révén megállapítható, hogy az alapjövedelem mellett növekedne az egyének kockázatvállalási hajlandósága, a nagyobb biztonság révén.

A közvetett kérdések esetén a munkavállalási motivációra és kockázatvállalásra adott válaszok azt mutatják, hogy a társadalmi és morális félelmek rejtetten, de nem alaptalanul fogalmazódnak meg, melyekre célszerű előre kidolgozni a válaszreakciókat. 


\section{KEZDŐKÖR}

\section{Irodalom}

ANKE, H. (2018): Unconditional basic income is a dead end. In: Downes, A. - Lansley, S. (eds.): It's Basic Income. The Global Debate. Bristol, Policy Press 113-116.

ARNOLD, C. (2018): Money for nothing: the truth about universal basic income news-feature. Nature, 2018/557.626-628.

ARTNERA. (2014): A feltétel nélkülialapjövedelem relevanciája és kérdőjelei. Eszmélet, 2014/102. 109-130.

ATKINSON, A. B. (2017): Egyenlőtlenség. Mit kellene tennünk? Budapest, Kossuth Kiadó

CSOBA J. (2010): A tisztes munka. A teljes foglalkoztatás: a 21. század esélye vagy utópiája? Budapest, L'Harmattan Kiadó.

DOWNES, A. - LANSLEY, S. (2018): Introduction. In: Downes, A. - Lansley, S. (eds.): It's Basic Income. The Global Debate. Bristol, Policy Press 1-13.

ESKELINEN, T. - PERKIÖ, J. (2018): Micro-investment perspective and the potential of the universal basic income. Development Policy Review, 2018/36. 696-709.

FORD, M. (2017): Robotok kora. Milyen lesz a világ munkahelyek nélkül? Budapest, HVG Kiadó.

FRIEDMAN, M. (1968): Negative Income Tax - I. Newsweek, 86-87.

GÁCS E. (1986): A garantált jövedelemről. Társadalomkutatás, 1986/3-4. 37-49.

GRAEBER, D. (2018): Bullshit Jobs: A Theory. New York, Simon \& Schuster.

HAYEK, F. (1979): Law, Legislation and Liberty - The Political Order of a Free People. Chicago, University of Chicago Press.

INGLEHART, R. - FLANAGAN, S. C. (1987): Value Change in Industrial Societies. The American Political Science Review, 1987/81. 1289-1319.

KITZINGER D. (2000): A morális pánik elmélete. Replika, 2000/40. 23-48.

MORUS T. (1963): Utópia. Budapest, Magyar Helikon.

PANITCH, V. (2011): Basic income, decommodification and the welfare state. Philosophy \& Social Criticism, 2011/37. 935-945.RAVENTOS, DANIEL (2007): Basic Income, The Material Conditions of Freedom. London, Pluto Press.

RODRIGUEZ-MONTEMAYOR, E. (2018): Could a universal basic income become the basis for working better in a fast-changing world? In: Downes, A. - Lansley, S. (eds.): It's Basic Income. The Global Debate. Bristol, Policy Press, 18-23.

ROTHSTEIN, B. (2018): FNA: rossz ötlet a jóléti állam szempontjából. Esély, 2018/4. 22-25.

RUCKERT, A. - HUYNH, C. - LABONTÉ, R. (2018): Reducing health inequities: is universal basic income the way forward? Journal of Public Health, 2018/40. 3-7. 
www. metszetek.unideb.hu

\section{KEZDŐKÖR}

SLOMAN, P. (2018): Universal Basic Income in British Politics, 1918-2018: From a 'Vagabond's Wage' to a Global Debate. Journal of Social Policy, 2018/47. 625-642.

STANDING, G. (2012): The Precariat: From Denizens to Citizens? Polity, 2012/44. Deepening Democracy, 588-608.

VAN PARIJS, P. (1992). Competing justifications of basic income. In: Van Parijs, P. (eds.): Arguing for basic income. London, Verso. 3-43.

VAN PARIJS, P. (2010): Alapjövedelem: egy egyszerű és erőteljes gondolat a huszonegyedik század számára. Esély, 2010/21. 9-41.

WEBER, M. (1982): A protestáns etika és a kapitalizmus szelleme. Budapest, Gondolat Kiadó.

WILDER, M. (2018): Debating Basic Income: Distributive Justice and the Normative-Technical Nexus. Canadian Journal of Political Science, 2018/51. 279-303.

WRIGHT, E. O. (2006): Basic Income as a Socialist Project. Basic Income Studies, 2006/1.1-11.

\section{Internetes hivatkozások}

A PÁRBESZÉD MAGYARORSZÁGÉRT KIADVÁNYA (2015): Alapjövedelem - biztos alap: neked is jár!

http://alapjovedelmet.hu/wp-content/uploads/2015/03/Alapjovedelem_vegleges.pdf (utolsó letöltés: 2019.01.07.)

BAKSAY, G. - BÓKAY, M. - PALOTAI, D. - SZALAI, Á. (2017): A feltétel nélküli alapjövedelem árnyoldalai. Magyar Nemzeti Bank Kiadványa.

https://www.mnb.hu/letoltes/baksay-bokay-palotai-szalai-a-feltetel-nelkuli-alapjovedelem-arnyoldalai.pdf (utolsó letöltés: 2019.01.07.)

BASIC INCOME EARTH NETWORK (2016): Definition in the current AISBL charter https://basicincome.org/wp-content/uploads/2016/09/Amendment_and_Motions_on_definition_of_BI.pdf (utolsó letöltés: 2019.01.07.)

CSILLAG, I. - MIHÁLYI, P. (2014): Tizenkét érv a feltétel nélküli alapjövedelemmel szemben. Élet és Irodalom. 2014. január 17.

https://www.es.hu/cikk/2014-01-17/csillag-istvan-mihalyi-peter/tizenket-erva-feltetel-nelkuli-alapjovedelemmel-szemben-.html (utolsóletöltés: 2019.01.07.)

LÉT (2014): 25-50-75 A LÉT. Ajánlat a magyar társadalomnak. Kézirat.

http://let.azurewebsites.net/upload/tanulmany.pdf (Utolsó letöltés: 2019.01.07.) 
www. metszetek.unideb.hu

\section{KEZDŐKÖR}

POLICY AGENDA (2018): Félelmek a munka világában.

https://library.fes.de/pdf-files/bueros/budapest/14591.pdf (utolsó letöltés: 2019. 01.07.)

REPUBLIKON (2016): Az alapjövedelem társadalmi megítélése

http://republikon.hu/elemzesek,-kutatasok/160520-alapjoevedelem.aspx (utolsó letöltés: 2019.01.07.)

TAKÁTS, P. (2014): A feltétel nélküli alapjövedelemről. Előadás a Drábik Alapítványnál http://menedzserkalauz.hu/wp-content/uploads/FNA-el\%C5\%91ad\%C3\%A1sa-Dr\%C3\%A1bik-Alap\%C3\%ADtv\%C3\%A1 nyn\%C3\%A1l.pdf (utolsó letöltés: 2019. 01.07.) 